\title{
Gambaran Pengetahuan, Sikap dan Perilaku Remaja Putri dalam Penanganan Keputihan di Desa Cilayung
}

\author{
Dinda Regia Febryary, ${ }^{1}$ Sri Astuti, ${ }^{2}$ Hartinah $^{2}$ \\ ${ }^{1}$ Program Diploma Kebidanan, Fakultas Kedokteran Universitas Padjadjaran \\ ${ }^{2}$ Departemen Ilmu Kesehatan Masyarakat, Fakultas Kedokteran Universitas Padjadjaran
}

\begin{abstract}
Abstrak
Berdasarkan hasil Survei Kesehatan Reproduksi Remaja Indonesia (SKRRI) tahun 2010 menunjukan bahwa remaja putri usia 15-24 tahun mempunyai risiko lebih tinggi terhadap infeksi atau keputihan patologis. Berdasarkan hasil survei mawas diri di desa Cilayung terdapat 226 remaja putri yang mengalami keputihan, sebagian besar remaja putri kurang memahami mengenai kesehatan reproduksi secara umum, khususnya dalam penanganan keputihan. Penelitian bertujuan untuk mengetahui gambaran pengetahuan, sikap, dan perilaku remaja putri dalam penanganan keputihan di Desa Cilayung. Metode penelitian yang digunakan adalah penelitian deskriptif. Sampel penelitian ini adalah 81 remaja putri yang ada di Desa Cilayung. Sampel yang dipilih yaitu Simple Random Sampling. Instrumen yang digunakan adalah kuisioner. Hasil penelitian ini menunjukan bahwa remaja putri yang berpengetahuan baik sebesar $61,7 \%$, remaja putri yang bersikap positif sebesar $56,8 \%$, remaja putri yang berperilaku positif sebesar $50,6 \%$, remaja putri yang berpengetahuan baik serta bersikap positif sebesar $68,0 \%$, dan remaja putri yang berpengetahuan baik serta berperilaku baik sebesar $62 \%$. Simpulan dari penelitian ini adalah penanganan keputihan yang dilakukan oleh remaja putri di Desa Cilayung dilihat dari tingkat pengetahuan, sikap, dan perilaku termasuk kedalam kategori baik.
\end{abstract}

Kata kunci : Penanganan Keputihan, Pengetahuan, Perilaku, Sikap

\section{Overview Knowledge, Attitudes, and Behaviors Teenage Girls in Handling of Leukorhea in the Cilayung Village}

\begin{abstract}
Based on data from Adolescent Reproductive Health Survey Indonesia (SKRRI) in 2010 showed that teenage girls aged 15-24 years have a higher risk of infection or pathological leukorhea. Based on the introspective survey results in the Cilayung village 226 teenage girls who have leukorhea, mostly teenage girl big less understanding regarding reproductive health in general, especially in the handling of leukorhea. The research aims to describe the knowledge, attitudes and behavior of teenage girls in the handling of leukorhea in the Cilayung village. The method used is descriptive research. Samples were 81 teenage girls in the Cilayung village. The selected sample is simple random sampling. The instrument used was a questionnaire. The results of this reseach showed that teenage girls good knowledge by $61.7 \%$, teenage girl be positive by $56.8 \%$, teenage girl behave positively by $50.6 \%$, teenager is good knowledge as well as being positive for $68.0 \%$, and teenage girl who are bothgood knowledge andwell behaved by $62 \%$. The conclusions of this study is treament of leukorhea by teenage girls in the Cilayung village seen from the level of knowledge, attitudes, and behaviors included into good category in handling of leukorhea
\end{abstract}

Keywords: Handling of Leukorea, Knowledge, Behavior, Attitudes

Korespondensi:

Dinda Regia Febryary

Program Diploma Kebidanan, Fakultas Kedokteran Universitas Padjadjaran

Jl. Raya Bandung-Sumedang km 21 Jatinangor

Mobile : 081319167120

Email : dindaregia77@gmail.com 


\section{Pendahuluan}

Masa remaja merupakan masa transisi dari anakanak menjadi dewasa. Pada

periode ini berbagai perubahan terjadi baik perubahan hormonal, fisik, psikologis maupun sosial. Remaja merupakan salah satu bagian dari populasi berisiko terkena keputihan yang perlu mendapat perhatian khusus. ${ }^{1,2}$

Keputihan adalah keluarnya cairan yang berlebihan dari vagina selain darah menstruasi. Keputihan ini merupakan keluhan yang umum terjadi pada wanita di dunia, terutama di wilayah Asia. World Health Organization (WHO) menyatakan bahwa 5\% remaja didunia terjangkit PMS dengan gejala keputihan setiap tahunnya, dan sebesar $75 \%$ wanita di seluruh dunia setidaknya mengalami candidiasis atau keputihan sebanyak satu kali dalam seumur hidupnya. ${ }^{2,4}$ Karena kurangnya pengetahuan dan informasi tentang keputihan yang didapatkan tidak akurat atau mungkin karena masih adanya mitos yang beredar di masyarakat terntang keputihan terutama pada remaja putri yang baru mulai memahami organ reproduksinya. ${ }^{2}$ Keputihan menjadi masalah besar yang tidak ditangani dengan serius oleh para perempuan. Padahal, keputihan bisa jadi indikasi adanya penyakit.

Dampak dari keputihan yang terlambat atau tidak diobati dapat berakibat buruk bagi kehidupan seorang wanita, seperti terjadinya infertil, endometritis, radang panggul, dan salpingitis. Kasus PMS khususnya klamidia terjadi sekitar $6,2 \%$ pada remaja usia $15-24$ tahun. ${ }^{5,6,7}$

Penyebab keputihan $70 \%$ karena jamur dan parasit seperti cacing kremi atau protozoa (Trichomonas vaginalis, serta infeksi jamur Candida albicans. ${ }^{7}$ Perilaku buruk dalam menjaga kebersihan genitalia dapat menjadi pencetus timbulnya infeksi yang menyebabkan keputihan tersebut. Jadi, pengetahuan dan perilaku dalam menjaga kebersihan genitalia eksterna merupakan faktor penting dalam pencegahan keputihan. ${ }^{10}$

Berdasarkan data Survei Kesehatan Reproduksi Remaja Indonesia (SKRRI) tahun 2010 menunjukan bahwa wanita yang rentan mengalami keputihan yaitu wanita yang berusia 15-24 tahun. Gejala keputihan yang dialami oleh remaja puteri, dalam 12 bulan terakhir menunjukkan remaja tersebut cukup banyak sebesar $31,8 \%$. Ini menunjukkan remaja putri mempunyai risiko lebih tinggi terhadap infeksi atau keputihan patologis. ${ }^{6}$ Keputihan atau flour albus harus segera ditangani, karena apabila tidak ditangani dalam jangka waktu yang lama akan menimbulkan komplikasi antara lain infertilitas, radang penyakit panggul dan penyakit menular seksual seperti klamidia diantaranya. ${ }^{7}$
Berdasarkan hasil survei mawas diri di daerah Cilayung tahun 2015, Jumlah penduduk berkisar 5312 Jiwa, dengan jumlah Remaja 425 jiwa, dan terdapat 226 remaja putri yang mengalami keputihan, beberapa diantaranya sebagian besar remaja putri kurang memahami mengenai kesehatan reproduksi secara umum, khususnya dalam penanganan keputihan.

Oleh karena itu penulis tertarik untuk mengetahui gambaran pengetahuan, sikap dan perilaku remaja putri dalam penanganan keputihan di Desa Cilayung.

\section{Metode}

Penelitian ini menggunakan metode penelitian deskriptif dengan pendekatan secara Cross Sectional. Populasi dalam penelitian ini adalah seluruh remaja perempuan 10-19 tahun di Desa Cilayung Kecamatan Jatinangor sebanyak 425 orang. Waktu penelitian dilaksanakan mulai tanggal 25 Agustus 2015 sampai 8 September 2015.

Teknik pengambilan sampel yang digunakan pada penelitian ini adalah teknik Random Sampling. Sampel dalam penelitian ini adalah remaja putri yang berusia 10-19 tahun di desa Cilayung yang berjumlah 81 orang. Kriteria inklusi dalam penelitian ini yaitu remaja yang berusia 10-19 tahun yang mengalami keputihan di Desa Cilayung, remaja yang belum menikah, remaja yang sudah menstruasi, dan remaja putri yang bersedia menjadi responden untuk diteliti. Untuk kriteria ekslusi dalam penelitian ini yaitu remaja yang tidak ada saat pengumpulan data. Variabel dalam penelitian ini adalah gambaran pengetahuan, sikap, dan perilaku remaja putri dalam penanganan keputihan. Data yang dikumpulkan pada penelitian ini berupa data primer. Dengan teknik Kuesioner dan sebagai instrumennya adalah daftar pertanyaan. Setelah semua data terkumpul, maka peneliti melakukan pengolahan data melalui beberapa tahap yaitu memeriksa ketepatan dan kelengkapan data. Data yang telah terkumpul dilihat kembali ketepatan dan kelengkapan datanya, kemudian dimasukkan kedalam program komputer. Data disajikan dalam bentuk distribusi frekuensi. Analasis data yang digunakan pada penelitian ini adalah univariat. Analisis univariat dalam penelitian ini dilakukan untuk mengetahui dan mendapatkan hasil terhadap gambaran pengetahuan, sikap dan perilaku remaja putri dalam penanganan keputihan. 


\section{Hasil}

Dari tabel 1, dapat diketahui bahwa pengetahuan remaja putri dalam penanganan keputihan dalam kategori baik sebesar $61,7 \%$, dan kurang sebesar $11,1 \%$, di tabel 2 , dapat diketahui bahwa remaja putri yang menangani keputihan dengan sikap positif sebesar 56,8\%, sedangkan sikap negatif sebesar 43,2\%. Dari tabel 3, remaja putri yang menangani keputihan dengan perilaku positif sebesar 50,6\%, sedangkan perilaku negatif sebesar 49,4\%. Berdasarkan dari tabel 4, dapat diketahui bahwa remaja putri yang menangani keputihan dengan pengetahuan baik dan sikapnya positif sebesar $68,0 \%$, pengetahuan baik dan sikap negatif sebesar 77,8\%. Dan dari tabel 5 menunjukan bahwa, remaja putri yang menangani keputihan dengan pengetahuan baik dan perilakunya positif sebesar $62 \%$, pengetahuan baik dan perilaku negatif sebesar 77,8\%.

Tabel 1 Distribusi Frekuensi Pengetahuan Remaja Putri dalam Penanganan Keputihan di Desa Cilayung

\begin{tabular}{|c|c|c|}
\hline Pengetahuan & $\mathbf{f}$ & $\%$ \\
\hline Baik & 50 & 61,7 \\
\hline Cukup & 22 & 27,2 \\
\hline Kurang & 9 & 11,1 \\
\hline Total & 81 & 100 \\
\hline
\end{tabular}

Tabel 2 Distribusi Frekuensi Sikap Remaja Putri dalam Penanganan Keputihan di Desa Cilayung

\begin{tabular}{lccc}
\hline & Sikap & f & \% \\
\hline Positif & 46 & 56,8 \\
Negatif & 35 & 43,2 \\
\hline Total & $\mathbf{8 1}$ & $\mathbf{1 0 0}$ \\
\hline
\end{tabular}

Tabel 3 Distribusi Frekuensi Perilaku Remaja Putri dalam Penanganan Keputihan di Desa Cilayung

\begin{tabular}{lccc}
\hline & Sikap & f & \% \\
\hline Positif & 41 & 50,6 \\
Negatif & 40 & 49,4 \\
\hline Total & $\mathbf{8 1}$ & $\mathbf{1 0 0}$ \\
\hline
\end{tabular}

Tabel 4 Tabulasi Silang Pengetahuan dengan Sikap Remaja Putri dalam Penanganan Keputihan di Desa Cilayung

\begin{tabular}{lccccccc}
\hline & \multicolumn{3}{c}{ Sikap } & & \multirow{2}{*}{ Total } \\
\cline { 2 - 7 } Pengetahuan & \multicolumn{3}{c}{ Positif } & f & Negatif & f & \% \\
\cline { 2 - 7 } Baik & f & \% & 16 & 32 & 50 & 100 \\
Cukup & 34 & 68 & 12 & 54,5 & 22 & 100 \\
Kurang & 10 & 45,5 & 7 & 77,8 & 8 & 100 \\
\hline
\end{tabular}


Tabel 5 Tabulasi Silang Pengetahuan dan Perilaku Remaja Putri dalam Penanganan Keputihan di Desa Cilayung

\begin{tabular}{|c|c|c|c|c|c|c|}
\hline \multirow[b]{3}{*}{ Pengetahuan } & \multicolumn{4}{|c|}{ Perilaku } & \multirow{2}{*}{\multicolumn{2}{|c|}{ Total }} \\
\hline & \multicolumn{2}{|c|}{ Positif } & \multicolumn{2}{|c|}{ Negatif } & & \\
\hline & f & $\%$ & f & $\%$ & f & $\%$ \\
\hline Baik & 31 & 62 & 19 & 38 & 50 & 100 \\
\hline Cukup & 8 & 36,4 & 14 & 63,6 & 22 & 100 \\
\hline Kurang & 2 & 22,2 & 7 & 77,8 & 9 & 100 \\
\hline
\end{tabular}

\section{Pembahasan}

Berdasarkan tabel 1, pengetahuan remaja putri di Desa Cilayung mengenai penanganan keputihan tergolong baik, walaupun masih ada yang memiliki pengetahuan yang cukup dan kurang. Pengetahuan remaja putri tentang tujuan dilakukannya penanganan keputihan masih kurang, padahal tujuan dari penanganan keputihan itu adalah untuk menghilangkan gejala keputihan, memberantas penyebab keputihan, dan mencegah terjadinya infeksi.

Menurut penelitian yang dilakukan oleh Meliza menunjukan sebesar $69,7 \%$ berpengetahuan baik, dan menyebutkan bahwa semakin dewasa umur seseorang, tingkat pengetahuan seseorang akan lebih matang atau lebih baik dalam berfikir dan bertindak. ${ }^{23}$ Hal ini juga sejalan dengan penelitian yang dilakukan oleh Ori Aprisia menunjukan sebesar $74,6 \%$ pengetahuan baik tentang keputihan, bahwa pengetahuan seseorang terhadap suatu objek mempunyai intensitas atau tingkat yang berbeda-beda. sumber informasi, usia, pendidikan, sosial, ekonomi, dan budaya dapat mempengaruhi tingkat pengetahuan seseorang. ${ }^{24}$ Berdasarkan pembahasan yang telah disampaikan, remaja putri yang memiliki pengetahuan yang baik itu dapat dipengaruhi oleh usia, dimana semakin dewasa umur seseorang, maka tingkat pengetahuan yang ia miliki akan semakin baik serta akan lebih matang atau lebih baik dalam.

Pada tabel 2 dapat diketahui bahwa sikap positif remaja putri yang menangani keputihan sebesar $56,8 \%$, walaupun masih terdapat sikap yang negatif. Sikap negatif yaitu tentang asumsi cebok yang baik dengan menggunakan sabun pembersih vagina. Sedangkan teori menyebutkan bahwa sabun pembersih vagina tidak dianjurkan untuk cebok, karena dengan pemakaian sabun vagina dapat merubah tingkat keasaman ph vagina, dan membunuh bakteri endogen yang terdapat di dalam vagina. Apabila bakteri ini mati karena penggunaan sabun pembersih vagina, maka tidak ada yang menjaga daerah kewanitaan dari bakteri lain yang mengganggu, sehingga berpotensi untuk menimbulkan infeksi karena timbulnya kuman yang lebih berbahaya.

Sikap positif ini diwujudkan dalam respon yang baik, yang merupakan kesiapan untuk bereaksi terhadap suatu objek dengan cara-cara tertentu. Hal-hal yang dapat membentuk sikap ialah pengalaman pribadi, pengetahuan yang dimilikinya, pengaruh orang lain yang dianggap penting, pengaruh kebudayaan, media massa, lembaga pendidikan dan lembaga agama, serta faktor emosional. Pengetahuan dan sikap akan menjadi landasan terhadap pembentukan moral remaja sehingga dalam diri seseorang idealnya ada keselarasan yang terjadi antara pengetahuan dan sikap, dimana sikap terbentuk setelah terjadi proses tahu terlebih dahulu.

Dalam penelitian Wahyu Febru yang bersikap positif dalam mengatasi keputihan sebesar $89 \%$, dalam penelitian ini disebutkan bahwa salah satu faktor yang mempengaruhi sikap seseorang ialah pengetahuan yang dimilikinya. Semakin baik pengetahuan terhadap suatu objek maka akan semakin baik pula sikap seseorang terhadap objek tersebut. ${ }^{22,24}$

Dari pembahasan ini, sikap remaja mengenai penanganan keputihan itu tergantung dari respon yang baik, yang merupakan kesiapan untuk bereaksi terhadap suatu objek serta hal-hal yang dapat membentuk sikap seperti pengalaman pribadi, pengaruh orang lain yang dianggap penting, pengaruh kebudayaan, media massa, lembaga pendidikan dan lembaga agama, faktor emosional dan pengetahuan yang dimiliki seseorang. Semakin tinggi pengetahuan yang ia miliki, maka semakin bagus pula cara remaja menyikapi dari penanganan keputihan.

Perilaku merupakan hasil dari segala macam pengalaman interaksi manusia dengan lingkungannya, yang terwujud dalam bentuk pengetahuan, sikap, dan tidakan yang dilakukan oleh responden terhadap kesehatan (pencegahan penyakit), cara peningkatan kesehatan, cara memperoleh pengobatan yang tepat, dan sebagainya. ${ }^{21}$ 
Pada tabel 3 remaja putri yang menangani keputihan dengan perilaku positif sebesar $50,6 \%$, sedangkan perilaku negatif sebesar $49,4 \%$. Perilaku negatif banyaknya yang jarang melakukan olahraga untuk menghindari stress, karena dalam teori mengatakan bahwa olahraga dianjurkan untuk menghilangkan stress. Semua organ tubuh kinerjanya di pengaruhi dan dikontrol oleh otak, maka ketika reseptor otak mengalami kondisi stress hal ini dapat menyebabkan terjadinya perubahan dan keseimbangan hormon-hormon dalam tubuh dan hal ini dapat menimbulkan terjadinya keputihan. Faktor utama yang mempengaruhi perilaku adalah sikap, pengetahuan, konsep diri, kepercayaan, nilai dan informasi. Kemudian faktor pendukung yaitu sarana dan prasarana, dan yang terakhir faktor pendorong yakni keluarga dan lingkungan sekitar. $^{33}$

Berdasarkan penelitian Ester Juliana yang menunjukan $70,1 \%$ responden bersikap positif, dan sama halnya dengan penelitian Egi yunia yang menunjukan sebesar $61 \%$ remaja putri bersikap positif dalam penanganan keputihan. Dalam penelitian ini objek perilaku yang diteliti adalah cara remaja putri dalam penanganan keputihan. Penilaiannya terdiri dari perilaku positif dan perilaku negatif. Perilaku positif maksudnya hasil dari pengalaman, pengetahuan, sikap, dan tindakan yang sesuai dalam cara penanganan keputihan yang baik dan benar. ${ }^{25,26}$

Dari pembahasan ini, perilaku seseorang dalam menangani keputihan itu diciptakan dari pengalaman yang dialami, pengetahuan yang dimiliki, dan dari bagaimana cara ia menyikapi suatu objek dengan baik.

Berdasarkan tabel 4 dan tabel 5 dapat diketahui bahwa remaja yang memiliki pengetahuan baik cenderung memiliki sikap positif $68,0 \%$ dan perilaku yang positif sebesar $62,0 \%$. Pengetahuan dan sikap datang dari pengalaman, pengetahuan juga bisa diperoleh dari informasi yang didapat, dan akan mempengaruhi sikap. Jika mempunyai pengetahuan tinggi, maka secara otomatis orang tersebut akan bersikap dan berperilaku sesuai dengan apa yang mereka ketahui. ${ }^{16}$

Dari hasil penelitian Fitria Ika, siswi yang memiliki pengetahuan baik akan bersikap dan berperilaku positif dalam mencegah leukorhea dibandingkan siswi yang memiliki pengetahuan cukup dan kurang. ${ }^{27}$

Mareta Wulan juga menyebutkan bahwa, semakin baik pengetahuan yang dimiliki oleh remaja putri tentang personal hygiene, maka tindakan pencegahan keputihan pada remaja putri juga akan semakin baik. ${ }^{28}$

Dari pembahasan diatas, pengetahuan yang baik mengenai penanganan keputihan, dapat menciptakan sikap yang positif serta perilaku yang positif pula dalam menanganan keputihan. Dalam teori Rosenberg, pengetahuan dan sikap berhubungan secara konsisten. Bila komponen kognitif (pengetahuan) berubah, maka akan diikuti perubahan sikap. ${ }^{34}$

Simpulan dari penelitian ini adalah sebagian besar remaja putri usia 10-19 tahun memiliki pengetahuan yang baik, sikap positi, dan perilaku positif dalam penanganan keputihan, sikap yang baik timbul karena pengalaman serta pengetahuan yang di dapat dari berbagai sumber, sehingga remaja putri mengetahui dan sadar tentang penanganan keputihan, remaja putri yang memiliki pengetahuan, pengalaman, dan informasi dari berbagai sumber serta sikap yang positif, dapat menghasilkan perilaku positif mengenai penanganan keputihan. Pengetahuan remaja putri yang baik, akan cenderung memiliki sikap yang positif dan perilaku yang positif.

Saran untuk penelitian ini adalah bidan desa selaku petugas kesehatan diharapkan dapat bekerja sama dengan kepala desa untuk meningkatkan pengetahuan remaja di Desa Cilayung, dalam kesehatan reproduksi khususnya dalam penanganan keputihan, Tokoh masyarakat di kecamatan Jatinangor dapat bekerjasama dengan puskesmas dan bidan desa di wilayah Desa Cilayung untuk membentuk PKPR, agar bisa menambah wawasan remaja di sekitar wilayah Jatinangor tersebut, Kepala desa dapat bekerjasama dengan bidan desa dan Puskesmas untuk menjalankan kembali PIK-KRR yang telah dibentuk, dan mengaktifkan kembali karang taruna di Desa Cilayung dalam meningkatkan pengetahuan dan keterampilan remaja dalam pencegahan masalah kesehatan khusus remaja.

Dalam penelitian ini terdapat keterbatasan, yaitu pada variabel gambaran pengetahuan, sikap, dan perilaku dalam penelitian ini menggunakan instrument penelitian berupa kuesioner. Sehingga rentan terjadi bias recall. Hal ini akan lebih baik apabila dilakukan pengambilan data dengan lembar observasi sesuai dengan pengambilan data.

\section{Daftar Pustaka}

1. Jose RL Battubara. Adolescent Development (Perkembangan remaja). Departemen Ilmu Kesehatan Anak, RS Dr Cipto Mangunkusumo, Fakultas Kedokteran Universitas Indonesia, Jakarta 2010;12(1):219)

2. Poltekes Depkes. Kesehatan remaja: problem dan solusinya. Jakarta: Salemba Medika. 2010 
3. Bahari, Hamid. Cara mudah atasi Keputihan. Jakarta:Buku Biru. 2012. hlm 9

4. Widyasari, Dian Tri. Faktor-Faktor yang berhubungan dengan Perilaku Pencegahan dan Penanganan Keputihan Patologis pada Mahasiswi Kebidanan STIK Bina Husada Palembang tahun 2014. Palembang: STIK Bina Husada

5. Williams H, Tabrizi SN, Lee W. Adolescence and other risk factors for Chlamydia trachomatis genitourinary infection in women in Melbourne, Australia. British Medical journal 2005; 31-32.

6. BPS (Badan Pusat Statistik), dan ORC MACRO. Survey Kesehatan Reproduksi Remaja Indonesia. Calveston, Maryland, USA : BPS dan ORC Macro. 2010

7. Curtis, Glade A. 17 Kehamilan:apa yang anda hadapi perminggu. Jakarta:Arcan. 2011 hlm 188

8. Djuanda A, Hamzah M, Aisah S. ilmu Penyakit Kulit \& Kelamin. 4th ed. Jakarta : Balai Penerbit FKUI. PP. 2007 hlm 89

9. Wandha Paramitha, Misrawati. Efektifitas Pendidikan Kesehatan tentang Hygine Kewanitaan terhadap Pengetahuan dan Sikap Remaja Putri dalam menangani Keputihan. Jurnal Ners Indonesia, 2012 : vol 2. Riau: UNRI

10. Manuaba, Ida Bagus. Penuntun Kepaniteraan Klinik Obstetri \&Ginekologi Edisi 2. Jakarta: EGC. 2004. hlm 242

11. Lapau, Buchari. Metodologi Penelitian Kebidanan. Jakarta: Pustaka Obor Indonesia.2015. 211-216

12. Ardayani, Tri. Pengetahuan dan Sikap Remaja dalam menangani Fluor Albus atau Keputihan Patologis di SMK 11 Bandung. Jurnal Kesehatan Budi Luhur volume 8 no.2. 2015 Cimahi: STIKES Budi Luhur

13. Budiharto. Metodologi penelitian kesehatan dengan contoh bidang ilmu kesehatan gigi. Jakarta: EGC. 2008 hlm 29-35

14. Maulana, Heri D.J. Promosi Kesehatan edisi 2. Jakarta : EGC. 2009 hlm 192-194

15. Sunaryo. Psikologi untuk Keperawatan. Jakarta: EGC; 2004. hlm 3-23

16. Fatrahady LB. Fluor albus (leukorea). 2007. www.fk-unram.ac.id.

17. Martaadisoebrata DJ, sjahid S, Thouw J, et al. Pedoman diagnosis dan terapi obstetri dan ginekologi rsup dr.Hasan Sadikin Bandung : Bagian / SMF Obstetri dan Ginekologi FKUP/RSUP Dr. Hasan Sadikin, 2005; 65-68

18. Hera., Rany Hiola. Hubungan Pengetahuan dengan Sikap Remaja Putri tentang Keputihan di SMP Negeri 11 Kota Gorontalo. 2014. Gorontalo: Universitas Negeri Gorontalo
19. Alhamda, Syukra. Buku Ajar Sosiologi Kesehatan. Yogyakarta: Pustaka Rihama. 2012. hlm 50-51

20. Sastrawinata, Sulaiman. Ginekologi. Ed_1981. Bandung : Bagian obstetri dan Ginekologi Fakultas kedokteran Universitas Padjadjaran. hlm 109-112

21. Hamdi, Asep Saepul., Bahrudin. Metode Penelitian Kuantitatif dan Kualitatif dalam Pendidikan. Yogyakarta: CV Budi Utama. 2012. hlm 18-50

22. Purnaningarti, Wahyu. Hubungan antara Tingkat Pengetahuan Remaja Putri tentang Keputihan dengan Sikap Remaja Putri dalam Mengatasi Keputihan di SLTPN 39 Semarang. 2011. Semarang

23. Amelia, Meliza., Yulia, Irvani., Darwin. Gambaran Perilaku Remaja Putri Menjaga Kebersihan Organ Genetalia dalam Mencegah Keputihan. 2012. FIK-UNRI

24. Putri, Ori P. Gambaran Tingkat Pengetahuan dan Sikap Remaja Putri terhadap Keputihan di SMA Negeri 2 Pontianak. 2014. FKUniversitas Tanjungpura

25. Rahmi, Egi Yunia., Arneliwati., Erwin. Faktor Perilaku yang mempengaruhi terjadinya Keputihan pada remaja Putri.2012 Riau: FIK-UNRI

26. Juliana, Ester., Ina Kuswanti, Fitria melina.. Hubungan Pengetahuan Remaja Putri Tentang Keputihan dengan Perilaku Pencegahan Keputihan di SMK BOPKRI 2 Yogyakarta. 2015. Yogyakarta: STIKES Yogyakarta

27. Wulandari, Fitria Eka., Wanda Junta. Hubungan Pengetahuan Personal Hygine dengan sikap dan perilaku mencegah Leukorhea pada Remaja Putri di SMK Dwija Dharma Mojosongo Boyolali. 2012. Surakarta: Akbid-Citra Medika

28. Permatasari, Mareta., Budi Mulyono.,dkk. Hubungan Tingkat pengetahuan Remaja Putri tentang Personal Hygine dengan Tindakan Pencegahan Keputihan di SMA Negeri 9 Semarang. 2012. Semarang: FIK-Universitas Muhamadiyah Semarang

29. Handayani, Hani. 2011. Hubungan Pengetahuan, Sikap dan Perilaku Remaja Putri tentang Keberhsihan Organ Genetalia Eksterna di Madrasah Tsanawiyah Pembangunan. 2011. Jakarta: FKIK-UIN

30. Sari, Dyan Lelyana. Persepsi Tentang Keputihan Pada Remaja Putri di SMP Negeri 29 Semarang. 2013. Semarang: FIKUniversitas muhamadiyah Semarang

31. Mokodonongan, Menthari H., Jhon Wantania., dkk. Hubungan Tingkat Pengetahuan Tentang Keputihan Dengan Perilaku Pencegahan Keputihan Pada Remaja Putri. 2015. Manado: 
FK- Universitas Sam Ratulangi

32. Wijayanti, F. A. Hubungan tingkat pengetahuan Wanita Penjaja Seks (WPS) tentang HIV/AIDS di Resosialisasi Argorejo Kelurahan Kali Banteng Kulon Semarang. 2009

33. Donatila, Novrinta A. Hubungan antara Pengetahuan dan Perilaku Menjaga
Kebersihan Genitalia Eksterna dengan Kejadian Keputihan pada Siswi SMA Negeri 4 Semarang. 2011. Semarang: FK-UNDIP

34. Sariyati, Susiana. Faktor-Faktor yang Mempengaruhi Sikap remaja putri tentang Fluor Albus di SMP Negeri 2 Trucuk Kabupaten Klaten. 2014. Yogyakarta: STIKES Alma Ata Yogyakarta. 